\title{
KEMAMPUAN PRODUKSI FONOLOGIS BAHASA INDONESIA ANAK PENYANDANG DOWN SYNDROME DI SDLB BANYUWANGI
}

\section{INDONESIAN PHONOLOGICAL PRODUCTION ABILITY OF CHILDREN WITH DOWN SYNDROME IN AN-MOERTY SPECIAL SCHOOL STUDENT BANYUWANGI}

\author{
Herlia Oktaviani $^{1}$, Asrumi ${ }^{2 *}$, Agustina Dewi Setyari ${ }^{3}$ \\ ${ }^{1}$ Alumni Fakultas Ilmu Budaya, Universitas Jember \\ ${ }^{2,3}$ Fakultas Ilmu Budaya, Universitas Jember \\ *Corresponding Author: asrumi.umi@gmail.com \\ Informasi Artikel: \\ Dikirim: 20/8/2018; Direvisi: 10/10/2018; Diterima: 7/12/2018
}

\begin{abstract}
This study examines the ability of phonological production or the ability to produce language sounds, namely vowels and consonants in Indonesian with Down syndrome, a student of the Banyuwangi An-Moerty Extraordinary Primary School. Phonological sensitivity has an important role in communicating creativity, including for persons with disabilities. The purpose of this study is to describe phonological production capabilities, and to find out the causes of the inability to pronounce language sounds of persons with Down syndrome, Bagus Chandra. This research is a qualitative research. This research data in the form of words spoken by Bagus Candra collected by the method of observation or observation with note-taking techniques and data in the form of information from the people closest to home and school were collected by interview method with note-taking techniques. Language data that have been classified are analyzed by distributional methods or agih methods with basic BUL techniques and advanced techniques: skipping, replacing, inserting, and changing the meanings, while data in the form of information are analyzed by descriptive analytical methods. The results of this study indicate that Bagus Chandra's phonological production ability in producing vowel sounds and consonant sounds is mostly perfect, because all vowel sounds [a], [i], [u], [e], and [o], and consonant sounds which includes sounds $[b],[c],[d],[g],[h],[j],[k],[l],[m],[n]$, $[p],[q],[s],[t]$, and $[y]$ can be pronounced correctly without obstacles. In this case, only a small part of the consonant sound, namely: sounds [r], [f], $[v],[w],[x]$, and, $[z]$ cannot be pronounced perfectly. Physically, the inability is caused by abnormal growth of the tongue, which is the size of the tongue that is longer and wider, and often extended.
\end{abstract}

Keywords: consonants, down syndrome, phonological production, vowels

Abstrak

Studi ini meneliti kemampuan produksi fonologis atau kemampuan untuk menghasilkan bunyi bahasa, yaitu vokal dan konsonan dalam bahasa Indonesia dengan sindrom Down, seorang siswa Sekolah Dasar Luar Biasa Banyuwangi An-Moerty. Sensitivitas fonologis memiliki peran penting dalam mengkomunikasikan kreativitas, termasuk bagi para penyandang cacat. Tujuan dari penelitian ini adalah untuk menggambarkan kemampuan produksi fonologis, dan untuk mengetahui penyebab ketidakmampuan mengucapkan bunyi bahasa orang dengan sindrom Down, Bagus Chandra. Penelitian ini adalah 
penelitian kualitatif. Data penelitian ini dalam bentuk kata-kata yang diucapkan oleh Bagus Candra dikumpulkan dengan metode observasi atau observasi dengan teknik mencatat dan data dalam bentuk informasi dari orang-orang terdekat ke rumah dan sekolah dikumpulkan dengan metode wawancara dengan teknik mencatat . Data bahasa yang telah diklasifikasikan dianalisis dengan metode distribusi atau metode agih dengan teknik BUL dasar dan teknik canggih: melompati, mengganti, memasukkan, dan mengubah makna, sedangkan data dalam bentuk informasi dianalisis dengan metode analisis deskriptif. Hasil penelitian ini menunjukkan bahwa kemampuan produksi fonologis Bagus Chandra dalam menghasilkan bunyi vokal dan bunyi konsonan sebagian besar sempurna, karena semua bunyi vokal [a], [i], [u], [e], [[]], dan konsonan suara yang meliputi suara $[\mathrm{b}],[\mathrm{c}],[\mathrm{d}],[\mathrm{g}],[\mathrm{h}],[\mathrm{j}],[\mathrm{k}],[\mathrm{l}],[\mathrm{m}],[\mathrm{n}],[\mathrm{p}],[\mathrm{q}]],[\mathrm{s}],[\mathrm{t}]$, dan $[\mathrm{y}]$ dapat diucapkan dengan benar tanpa hambatan. Dalam hal ini, hanya sebagian kecil dari bunyi konsonan, yaitu: bunyi $[\mathrm{r}],[\mathrm{f}],[\mathrm{v}],[\mathrm{w}],[\mathrm{x}]$, dan, $[\mathrm{z}]$ tidak dapat diucapkan dengan sempurna. Secara fisik, ketidakmampuan tersebut disebabkan oleh pertumbuhan lidah yang tidak normal, yaitu ukuran lidah yang lebih panjang dan lebih lebar, dan sering memanjang.

Kata kunci: konsonan, down syndrome, produksi fonologis, vokal

\section{PENDAHULUAN}

Penelitian ini membahas tentang kemampuan anak penyandang disabilitas down syndrome dalam memproduksi bunyi-bunyi bahasa, yakni vokal dan konsonan. Hal ini penting dilakukan karena kemampuan produksi fonologis akan berpengaruh pada berpikir dan berkomunikasi. Hal ini akan mengganggu pemahaman lawan tutur karena bicaranya terdengar samar-samar dan patah-patah.

Penelitian tentang kemampuan menghasilkan bunyi-bunyi bahasa pada anak disabilitas down syndrome pada dasarnya sudah sering dilakukan, seperti yang telah dilakukan Sudiono (2014:87) bahwa kelainan pada sistem syaraf mempengaruhi kemampuan bicara dan tingkah laku penderita down syndrome. Rondal (dalam Baihaqi, 2011:154) menyebutkan bahwa beberapa kelemahan dalam perkembangan bahasa anak down syndrome meliputi: (1) penggunaan kalimat yang lebih pendek dan sederhana disertai gangguan artikulasi, (2) penggunaan arti kata yang lebih konkret, dan (3) penggunaan yang lebih sedikit dari berbagai fungsi semantik seperti keterangan tempat dan waktu. Kumin (dalam Cohen, Nadel, dan Madnick, 2002:396) menyatakan bahwa di antara bahasa, komunikasi, dan bicara, bicara merupakan hal paling sulit bagi anak-anak down syndrome. Selain itu, Roberts, Price, Malkins (2007:26) berpendapat bahwa down syndrome adalah penyebab paling umum dari keterbelakangan mental. Menurut Indah (2012:127), down syndrome atau keterbelakangan mental menunjukkan adanya hubungan kelainan kognitif dengan kegagalan memperoleh kompetensi linguistik sepenuhnya. Rondal (dalam Baihaqi 2011:154) menyatakan dari kemampuan intelegensi, interaksi, dan berbahasa, kemampuan berbahasa menduduki posisi terendah. Kelemahan perkembangan bahasa ini dinyatakan dalam bentuk kekurangmampuan perbendaharaan kata-kata, kelemahan artikulasi, kebiasan berbicara dengan menggunakan kata-kata yang terpisah. Selain itu, Dodd (dalam Pruthi 2007:5) menerangkan dari segi perkembangan fonologis anak down syndrome cenderung memperlihatkan adanya gangguan artikulasi. Smith (dalam Pujaningsih, 2010:51) menyatakan bahwa beberapa penyebab yang memungkinkan gangguan artikulasi antara lain adalah cleft palate, kelainan pita suara, lidah 
tebal atau pendek, dll. Pernyataan Smith tersebut, didukung oleh pernyataan Rondal (dalam Indah, 2012:128) bahwa kebanyakan penyandang down syndrome mengalami masalah serius dalam organ wicara dan artikulasi yang disebabkan oleh: (1) rongga mulut yang terlalu sempit sehingga menyulitkan lidah menghasilkan suara resonansi, lidah menjulur, bibir sumbing atau langit-langit pendek, struktur gigi yang tidak normal atau cacat yang menyebabkan oklusi gigi, pangkal tenggorok berada di leher atas, otot wicara lemah yang terkait dengan lidah, bibir, langit-langit dan otot pernafasan, (2) gangguan pendengaran, (3) lemah dalam koordinasi motorik, dan (4) masalah bersuara. Berdasarkan hasil-hasil penelitian tersebut belum ada yang membahas tentang kemapuan produksi fonologis, vokal dan konsonan pada penderita disabilitas down syndrome.

Penelitian lain yang membahas kemampuan produksi bunyi-bunyi bahasa yang mirip dengan penelitian ini telah dilakukan dengan objek yang sama-sama penyandang disabilitas, tetapi berbeda jenis disabilitasnya, yakni penyandang tunagrahita. Pertama, Khotimah (2016) menyatakan bahwa seorang penyandang disabilitas tunagrahita, Maulidiyah telah menguasai bunyi-bunyi vokal [a], [u], [o], dan [o], sedangkan vokal yang tidak dikuasai adalah vokal [e], [i], [ə], dan $[\varepsilon]$ karena terjadi perubahan. Bunyi-bunyi konsonan yang tidak dikuasai meliputi bunyi [f], [q], [r], [s], dan [v] dan terjadi monotongisasi, yakni bunyi [ai] diucapkan [E] sedangkan bunyi [au] diucapkan [o]. Kajian lain oleh Mardiati (2018) yang menyatakan bahwa kemampuan pelafalan bunyi-bunyi bahasa dalam kosakata dasar bahasa Indonesia oleh anak tunagrahita, Lutsiana, khususnya bunyi-bunyi vokal cenderung normal, namun dalam pelafalan silabe terbuka biasanya terdapat penambahan bunyi glotal [?]. Dalam pelafalan bunyi-bunyi konsonan terdapat penghilangan bunyi-bunyi $[\mathrm{d}],[\mathrm{h}],[\mathrm{m}],[\mathrm{n}],[\mathrm{r}]$, dan [ñ $]$ pada kata-kata tertentu. Selain itu, juga terjadi penggantian bunyi-bunyi konsonan, yakni: $[\mathrm{g}]$ menjadi [y], bunyi [r] menjadi [l, y, m]; bunyi [s] menjadi [t]; bunyi [n] menjadi [n, l]; bunyi [b] menjadi [p]; bunyi [1] menjadi [b]; dan bunyi [p] menjadi [m]. Berdasarkan hasil-hasil penelitian tersebut diprediksi memiliki perbedaan dan persamaan dengan penelitian ini.

Abdurrahman dan Sudjadi (dalam Sardjono, 2005:14) menyatakan bahwa kelainan atau gangguan bicara/wicara/tuna wicara adalah suatu kerusakan atau gangguan dari suara, artikulasi dari bunyi wicara, dan atau kelancaran wicara. Gangguan-gangguan atau kerusakan tersebut dapat diamati dalam pengiriman dan penggunaan sistem simbol oral. Selain itu, ketidaklancaran berujar juga merujuk pada kegagalan dan kekurangmampuan seseorang dalam berkomunikasi dengan bahasa lisan yang lancar dan berkesan Lahey (dalam Muslich, 2014:20-21). Chaer (2003:149-165) merinci gangguan bicara berdasarkan mekanisme sebagai suatu proses produksi ucapan atau perkataan oleh kegiatan terpadu dari pita suara, lidah, otototot yang membentuk rongga mulut serta kerongkongan, dan paru-paru. Ganguan bicara berdasarkan mekanismenya dirinci menjadi gangguan berbicara akibat kelainan pada paruparu (pulmonal), pita suara (laringal), lidah (lingual), rongga mulut serta kerongkongan (resonantal). Berdasarkan penjelasan di atas, peneliti bermaksud untuk meneliti kemampuan produksi fonologis atau kemampuan dalam menghasilkan bunyi-bunyi bahasa dari penderita down syndrome, dan faktor penyebab ketidakmampuan pengucapan bunyi bahasanya. Dalam hal ini, subjek penelitian hanya satu orang yaitu Bagus Chandra. Bagus Chandra, adalah salah 
satu penderita down syndrome yang saat ini bersekolah di Sekolah Dasar Luar Biasa AnMoerty Banyuwangi, yang menderita kelainan genetika down syndrome sejak dilahirkan, dan mengalami beberapa gangguan dalam berbahasa. Gangguan berbahasa yang paling terlihat adalah gangguan artikulasi saat Bagus Chandra mengucapkan beberapa bunyi konsonan, salah satunya adalah bunyi konsonan [r]. Dalam hal ini, bunyi konsonan [r] diucapkan menjadi [1]. Pengucapan bunyi konsonan [r] menjadi [1] membentuk pola yang berulang-ulang karena selalu terjadi baik di awal, tengah, maupun di akhir kata. Oleh karena itu, tujuan penelitian ini adalah untuk mendeskripsikan kemampuan produksi bunyi-bunyi bahasa (vokal dan konsonan) dan faktor-faktor yang melatarbelakangi ketidakmampuan produksi bunyi-bunyi bahasa penderita disabilitas down syndrome, Bagus Candra.

\section{METODE}

Penelitian ini adalah penelitian kualitatif. Lokasi penelitian ini di Sekolah Dasar Luar Biasa An-Moerty Banyuwangi. Data penelitian ini adalah data kebahasaan atau data lingual berupa kata-kata dari alat ucap yang dihasilkan oleh Bagus Chandra. Selain itu, data yang lain adalah data informasi mengenai kelainan genetika yang mengakibatkan down syndrome yang saat ini diderita oleh Bagus Chandra dari orang-orang terdekat di rumah dan sekolah. Sumber data diperoleh dari subjek yaitu Bagus Chandra. Selain itu, sumber data juga diperoleh dari beberapa informan, yaitu orang tua, psikolog, dan juga guru pembimbing di Sekolah Dasar Luar Biasa An-Moerty Banyuwangi. Metode pengumpulan data dalam penelitian ini menggunakan metode simak atau observasi dengan teknik catat, dan metode cakap atau wawancara mendalam dengan teknik rekam, pancing, dan catat untuk memperoleh data mengenai faktor yang menyebabkan subjek penelitian mengalami ketidakmampuan dalam mengucapkan bunyi bahasa.

Metode analisis data pada penelitian ini adalah metode deskriptif analitis dan menggunakan metode distribusional atau metode agih untuk menganalisis aspek lingual dari subjek penelitian. Metode deskriptif analitis adalah suatu metode yang berfungsi untuk mendeskripsikan atau memberi gambaran terhadap objek yang diteliti melalui data atau sampel yang telah terkumpul sebagaimana adanya tanpa melakukan analisis dan kesimpulan yang berlaku untuk umum (Sugiyono, 2008:29). Adapun metode agih dalam penelitian ini menggunakan teknik distribusi yaitu teknik bagi unsur langsung (BUL). Teknik BUL pelaksanaannya mengandalkan intuisi peneliti dengan cara memilah aspek lingual yang dihasilkan oleh alat ucap subjek. Selanjutnya, teknik lanjutan yang digunakan adalah teknik lesap, ganti, sisip, dan ubah ujud. Teknik lesap dalam penelitian ini untuk membuktikan adanya pelesapan unsur gramatikal dalam bunyi bahasa. Teknik sisip digunakan untuk membuktikan adanya penyisipan (adisi) dari bunyi bahasa yang diucapkan, hal ini dibuktikan dengan contoh kata [dasi] yang diucapkan menjadi [dasI ${ }^{\mathrm{h}}$ ]. Teknik lesap digunakan untuk membuktikan adanya penghilangan (omisi) seperti pada contoh kata [wali] yang diucapkan menjadi [ali] oleh Bagus Chandra. Lalu, teknik ganti digunakan untuk membuktikan adanya penyulihan (substitusi) seperti pada contoh kata [rakUs] yang diucapkan menjadi [lakUs] oleh Bagus Chandra. 


\section{HASIL DAN PEMBAHASAN}

\section{Produksi Bunyi-bunyi Vokal}

Produksi bunyi-bunyi vokal yang dihasilkan Bagus Chandra dapat dikatakan sempurna, sebab ia mampu melafalkan seluruh bunyi vokal yang mencakup bunyi [a], [i], [u], [e], dan [o] dalam bahasa Indonesia. Adapun hal ini didasarkan pada distribusi dan pada silabe terbuka serta tertutupnya bunyi vokal yang dihasilkan oleh alat ucap Bagus Chandra. Hal ini dapat dikatakan unik, sebab beberapa dari hasil penelitian sejenis sebelumnya menunjukkan bahwa, pengujaran bunyi bahasa dari anak down syndrome mengalami penyimpangan bunyi baik vokal maupun konsonan. Selain itu, anak yang memiliki kelainan down syndrome mengalami kesulitan dalam mengujarkan lebih dari dua kata dengan bahasa yang tidak jelas (Baihaqi, 2011). Adapun uraian lengkapnya dijelaskan pada Tabel 1.

Tabel 1. Produksi Bunyi Vokal

\begin{tabular}{|c|c|c|c|c|}
\hline No. & Vokal & $\begin{array}{c}\text { Suku Awal dan Silabe } \\
\text { Terbuka }\end{array}$ & $\begin{array}{l}\text { Suku Tengah dan } \\
\text { Silabe Tertutup }\end{array}$ & Suku Akhir \\
\hline 1 & [a] & [angsa] / [ã̃sa] & [katak] / [kata?] & [rusa] / [lusa] \\
\hline & [i] & {$[\mathrm{ibu}] /\left[\mathrm{ibU}^{\mathrm{h}}\right]$} & [pasir] / [pasIl] & {$[\mathrm{sapi}] /\left[\mathrm{sapI}^{\mathrm{h}}\right]$} \\
\hline 3. & {$[\mathrm{u}]$} & {$[\mathrm{ubi}] /\left[\mathrm{ubI}^{\mathrm{h}}\right]$} & [belut] / [bəlUt] & {$[\mathrm{kamu}] /\left[\mathrm{kamU}^{\mathrm{h}}\right]$} \\
\hline & [ə] $[\mathrm{e}]$ & [emas] / [əmas] & [pərətas] / [pələtas] & [sate] / [sate] \\
\hline & [०] & [obor] / [obol] & [balon] / [balon] & [soto] / [soto $\left.{ }^{h}\right]$ \\
\hline
\end{tabular}

Dalam hal ini dijelaskan produksi bunyi vokal yang mampu diucapkan dengan sempurna oleh Bagus Chandra. Seluruh kemampuan pengucapan bunyi vokal di atas didasarkan pada distribusi bunyi dan juga silabe terbuka dan tertutup. Adapun produksi bunyi-bunyi vokal yang dihasilkan Bagus Chandra dapat dikatakan sempurna, sebab ia mampu melafalkan seluruh bunyi vokal yang mencakup bunyi [a], [i], [u], [ə][e], dan [o] dalam bahasa Indonesia.

Berdasarkan tabel di atas, dapat dikatakan bahwa kemampuan bunyi vokal Bagus Chandra adalah sempurna, hal ini dibuktikan dengan beberapa contoh bunyi vokal [a], [i], [u], [ə][e], dan [0] dengan contoh kata masing-masing yang menempati distribusi dan juga silabe terbuka dan tertutup. Sebagai contoh bunyi vokal [a] dengan contoh kata [angsa] diucapkan menjadi [ã̃sa] pada suku awal dan juga silabe terbuka, kata [katak] diucapkan menjadi [kata?] pada suku tengah dan silabe tertutup, dan kata [rusa] diucapkan menjadi [lusa] pada suku akhir.

Bunyi vokal [a] tidak berubah menjadi bunyi vokal yang lain ketika berada di suku awal, tengah, dan akhir, serta silabe terbuka dan tertutup. Hal ini dapat membuktikan bahwa bunyi vokal [a] adalah sempurna, hal ini juga berlaku pada bunyi-bunyi vokal yang lain, yang 
mencakup bunyi vokal [i], [u], [ə][e], dan [ə] dengan contoh kata masing- masing berdasarkan tabel di atas.

\section{Produksi Bunyi Konsonan}

Dalam hal ini, akan dijelaskan tentang bunyi konsonan yang mampu diucapkan dan tidak mampu diucapkan oleh alat ucap Bagus Chandra yang mencakup. Bunyi konsonan yang mampu diucapkan mencakup bunyi konsonan $[\mathrm{b}],[\mathrm{c}],[\mathrm{d}],[\mathrm{g}],[\mathrm{h}],[\mathrm{j}],[\mathrm{k}],[\mathrm{l}],[\mathrm{m}],[\mathrm{n}],[\mathrm{p}]$, [q], [s], [t], dan [y]. Bunyi-bunyi konsonan yang mampu diucapkan adalah bunyi konsonan yang tidak mendapatkan hambatan ketika dilafalkan, dengan kata lain bunyi konsonan ini adalah bunyi konsonan yang sempurna. Adapun bunyi-bunyi konsonan yang tidak mampu diucapkan yaitu bunyi konsonan $[\mathrm{r}],[\mathrm{f}],[\mathrm{v}],[\mathrm{w}],[\mathrm{x}]$, dan [z]. Uraian lengkapnya dijelaskan pada Tabel 2 sebagai berikut.

Tabel 2. Produksi Bunyi Konsonan

\begin{tabular}{|c|c|c|c|c|}
\hline No. & $\begin{array}{l}\text { Konsonan } \\
\text { mampu } \\
\text { diucapkan }\end{array}$ & $\begin{array}{c}\text { Suku Awal dan Silabe } \\
\text { Terbuka }\end{array}$ & $\begin{array}{l}\text { Suku Tengah dan } \\
\text { Silabe Tertutup }\end{array}$ & Suku Akhir \\
\hline & [b] & [buta] / [ buta $\left.^{\mathrm{h}}\right]$ & [kabut] / [kabUt] & [wajib] / [ajIb] \\
\hline 2. & [c] & [cicak] / [cica?] & [kaca] / [kaca] & - \\
\hline & [d] & [domba] / [domba] & [kedip] / [kədIp] & [wujud] / [ujUd] \\
\hline 4. & [g] & [gigi] / gigI $\left.^{\mathrm{h}}\right]$ & [gagak] / [gaga?] & [gudəg] / [gudəg] \\
\hline 5. & {$[\mathrm{~h}]$} & [hari] / [hallh] & [mahal] / [mahal] & [indah] / [indah] \\
\hline 6. & [j] & [jam] / [jam] & {$[\mathrm{keju}] /[\mathrm{keju}]$} & [mikraj] / [milklaj] \\
\hline 7. & {$[\mathrm{k}]$} & [kuda] / [kuda] & [suka] / [suka] & [landak]/ [landa?] \\
\hline 8. & [1] & [lada] / [lada] & [malas] / [malas] & [kapal] / [kapal] \\
\hline & {$[\mathrm{m}]$} & {$[\mathrm{maju}] /\left[\mathrm{maj}^{\mathrm{h}}\right]$} & [kuman] / [kuman] & [padam] / [padam] \\
\hline & {$[\mathrm{n}]$} & [naga] / [naga] & [tunas] / [tunas] & [bensin] / [bensIn] \\
\hline & [p] & [papa] / [papa] & [kapak] / [kapa?] & [kecap] / [kecap] \\
\hline 12 & [q] & [quran] / [qulan] & - & - \\
\hline & {$[\mathrm{s}]$} & [sama] / [sama] & {$[$ sisir] / [sisIl] } & [kapas] / [kapas] \\
\hline & {$[\mathrm{t}]$} & [tali] / [tali] & [matang] / [matã̃] & [səmut] / [səmUt] \\
\hline \multirow[t]{2}{*}{15.} & {$[\mathrm{y}]$} & [yasin] / [yasIn] & [sayur] / [sayUl] & - \\
\hline & $\begin{array}{l}\text { Konsonan } \\
\text { tidak mampu } \\
\text { diucapkan }\end{array}$ & $\begin{array}{l}\text { Suku Awal dan Silabe } \\
\text { Terbuka }\end{array}$ & $\begin{array}{l}\text { Suku Tengah dan } \\
\text { Silabe Tertutup }\end{array}$ & Suku Akhir \\
\hline
\end{tabular}


Kemampuan Produksi Fonologis Bahasa Indonesia Anak Penyandang Down Syndrome di SDLB Banyuwangi (Herlia Oktaviani, Asrumi, Agustina Dewi Setyari)

\begin{tabular}{|c|c|c|c|}
\hline 16. $[\mathrm{r}]$ & [rapi] / [lapI ${ }^{\mathrm{h}]}$ & [kerang] / [kəlañ] & [pasar] / [pasal] \\
\hline 17. [f] & [fauna] / [pauna] & [kefir] / [kəpIl] & [saf] / [sap] \\
\hline 18. [v] & [vas] / [pas] & - & - \\
\hline 19. [w] & [wajah] / [ajah] & [sawit] / [saIt] & - \\
\hline 20. $[\mathrm{x}]$ & [xenon] & - & - \\
\hline 21. $[z]$ & [zaman] / [jaman] & [lazim] / [lajIm] & [juz] / [jUj] \\
\hline
\end{tabular}

Berdasarkan Tabel 2 tersebut, dijelaskan tentang bunyi konsonan yang mampu diucapkan oleh alat ucap Bagus Chandra yang mencakup bunyi konsonan [b], [c], [d], [g], [h], [j], [k], [1], [m], [n], [p], [q], [s], [t], dan [y]. Bunyi-bunyi konsonan yang mampu diucapkan adalah bunyi konsonan yang tidak mendapatkan hambatan ketika dilafalkan, dengan kata lain bunyi konsonan ini adalah bunyi konsonan yang sempurna. Bunyi-bunyi konsonan yang mampu diucapkan dalam hal ini juga didasarkan pada distribusinya serta pada silabe terbuka dan tertutup.

Bunyi konsonan yang mampu diucapkan oleh Bagus Chandra salah satunya adalah bunyi konsonan [b] dengan contoh kata [buta] yang dilafalkan menjadi [buta ${ }^{\mathrm{h}}$ ] yang terletak pada suku awal dan silabe terbuka, suku tengah dan silabe tertutup pada kata [kabut] yang diucapkan menjadi [kabUt], dan suku akhir pada kata [wajib] yang diucapkan menjadi [ajIb]. Bunyi konsonan [b] tersebut tidak berubah menjadi bunyi konsonan yang lain meskipun ia berada pada suku awal, tengah, dan akhir, serta silabe terbuka dan tertutup. Hal ini juga terbukti dengan contoh bunyi konsonan yang lain yang mencakup bunyi konsonan [c], [d], [g], [h], [j], [k], [1], [m], [n], [p], [q], [s], [t], dan [y].

Adapun bunyi konsonan yang tidak mampu diucapkan adalah bunyi konsonan [r], [f], [v], [w], [x], dan [z]. Sebagai contoh adalah bunyi konsonan [r] dengan contoh kata [rapi] yang diucapkan menjadi $\left[\mathrm{lapI}^{\mathrm{h}}\right.$ ] pada suku awal dan silabe terbuka, kata [kerang] yang diucapkan menjadi [kəlañ] pada suku tengah dan silabe tertutup, dan kata [pasar] yang diucapkan menjadi [pasal] pada suku akhir. Bunyi konsonan [r] selalu berubah menjadi bunyi konsonan [1], ketika bunyi konsonan [r] tersebut berada pada suku awal, tengah, dan akhir, serta silabe terbuka dan tertutup. Hal seperti ini, selalu terjadi berulang-ulang dan teratur. Adapun pengucaan bunyi konsonan yang tidak sempurna juga terjadi ketika bunyi konsonan [f], [v], [w], [x], dan [z] diucapkan oleh Bagus Chandra

\section{Faktor Penyebab Ketidakmampuan Pengucapan Bunyi Bahasa}

Berdasarkan observasi di lapangan yang telah dilakukan oleh peneliti, salah satunya adalah hasil wawancara dengan orang tua Bagus Chandra, bahwa kelainan genetika down syndrome yang dialami oleh Bagus Chandra menurut dokter yang dahulu menangani Bagus Cahndra yakni disebabkan oleh virus yang disebarkan oleh hewan ternak saat ibu dari Bagus 
Chandra mengandung. Sehingga ketika dilahirkan, terjadi abnormalitas kinerja tubuh yang terlihat baik secara mental dan fisik pada Bagus Chandra. Secara mental, kelainan genetika trisomy 21 menyebabkan gangguan mental pada otak dan menyebabkan Bagus Chandra memiliki tingkat intelegensia rendah, yaitu intelengensia pada rentang 35-40. Sehingga saat ini, IQ yang dimiliki oleh Bagus Chandra masuk dalam kategori moderate mental retardation, yaitu penderita kelainan down syndrome dengan tingkat IQ atau intelegensia yang menengah. Pada kategori ini, Bagus Chandra mengalami keterlambatan dalam perkembangan bahasa, dan juga seringkali tidak mampu beradaptasi di sekolah biasa, sehingga saat ini ia perlu menempuh pendidikan di sekolah berkebutuhan khusus untuk menunjang kelancaran dalam proses akademisnya. Secara fisik, ditemukan gangguan tumbuh kembang lidah yang tidak normal. Ukuran lidah yang dimiliki oleh Bagus Chandra cenderung lebih panjang dan lebar dan cenderung dijulurkan. Untuk membuktikannya, peneliti mengukur panjang lidah Bagus Chandra dengan menggunakan alat ukur panjang dalam hal ini adalah jangka. Teknik yang digunakan adalah dengan mengukur panjang dan lebar lidah Bagus Chandra ketika lidah dalam keadaan istirahat. Hasil yang didapatkan setelah pengukuran menunjukkan bahwa ukuran lidah lebih panjang dan juga lebih lebar. Bagus Chandra memiliki ukuran lidah dengan panjang kurang lebih $5,5 \mathrm{~cm}$ dan lebar $4,8 \mathrm{~cm}$ sedangkan panjang dari rahang bawahnya adalah 4,5 cm dan lebar $4 \mathrm{~cm}$. Dalam hal ini, ukuran normal lidah seseorang dapat diketahui dengan cara membandingkan antara panjang dan lebar rahang bawah dengan panjang dan lebar lidahnya. Sehingga, dalam kondisi ini, dapat dikatakan bahwa Bagus Chandra mengalami abnormalitas ukuran pada lidah. Ukuran lidah yang tidak normal tersebut, dapat dikatakan adalah hal yang menyebabkan kesalahan pengucapan bunyi bahasa Bagus Chandra. Sehingga, ketika berkomunikasi dengan lawan bicara, beberapa bunyi bahasa yaitu bunyi konsonan yang mencakup bunyi konsonan [r], [f], [v], [w], [x], dan [z] tidak mampu ia ucapkan dengan sempurna. Adapun bunyi konsonan yang tidak mampu diucapkan, mencakup bunyi konsonan $[\mathrm{r}],[\mathrm{f}],[\mathrm{v}],[\mathrm{w}],[\mathrm{x}]$, dan [z]. Untuk penjelasan lebih lengkapnya sebagai berikut.

\section{Bunyi Konsonan Apiko-alveolar [r]}

Bunyi konsonan apiko-alveolar [r] berdasarkan mekanisme artikulasinya masuk ke dalam konsonan getar apiko-alveolar, yaitu peran ujung lidah sebagai artikulator aktif dan gusi sebagai artikulator pasif. Dengan kondisi lidah yang terlalu panjang dan juga lebar menyebabkan Bagus Chandra tidak mampu mengucapkan bunyi konsonan [r]. Hal ini dikarenakan, Bagus Chandra tidak mampu menyentuhkan ujung lidah secara leluasa ke gusi atas bagian belakang sehingga lidahnya tidak mampu membentuk lengkungan dan tidak bisa merapat, serta merenggang berkali-kali pada gusi atas bagian belakang. Sehingga udara tidak bisa digetarkan. Oleh sebab itu, bunyi konsonan [r] tidak mampu diucapkan, dan diganti dengan bunyi konsonan [1] yang dinilai lebih mudah untuk diucapkan.

\section{Bunyi Konsonan Labio-dental [f] dan [v]}

Bunyi konsonan labio-dental [f] dan [v] juga tidak mampu untuk diucapkan. Bunyi konsonan labio-dental [f] dan [v] dibentuk dengan cara bibir bawah yang berperan sebagai artikulator aktif, dan gigi atas sebagai artikulator pasif. Dalam pembentukan bunyi konsonan 
[f] dan [v], Bagus Chandra tidak mampu menekankan bibir bawah pada gigi depan atas karena keadaan lidah yang terlalu panjang sehingga menghalangi bibir bawah dalam menyentuh gigi depan atas, sehingga tidak terjadi penyempitan jalan arus udara yang menyebabkan tidak ada udara yang keluar melalui sela-sela bibir dengan gigi, dan juga melalui lubang-lubang yang berada diantara gigi. Oleh karena itu, saat bunyi konsonan [f] dan juga [v] tidak mampu diucapkan, Bagus Chandra mengganti bunyi konsonan [f] dan [v] tersebut dengan bunyi konsonan [p].

\section{Bunyi Konsonan Bilabial [w]}

Bunyi konsonan bilabial [w], yaitu melibatkan peran bibir bawah sebagai artikulator aktif dan bibir atas sebagai artikulator pasif. Dalam kondisi ini, buni konsonan bilabial [w] tidak mampu diucapkan, sebab bibir bawah tidak mampu dirapatkan ke bibir atas karena terhalang oleh kondisi lidah yang panjang dan menjulur. Selain itu, pangkal lidah yang berperan untuk naik mendekati langit-langit lunak dalam keadaan ini tidak mampu dilakukan oleh Bagus Chandra, sehingga tidak ada bunyi konsonan bilabial [w] yang terbentuk. Seringkali dalam pelafalan bunyi konsonan bilabial [w] bunyi tersebut dihilangkan baik posisinya berada di suku kata awal dan tengah oleh Bagus Chandra.

\section{Bunyi Konsonan Dorso-velar [x]}

Bunyi konsonan dorso-velar [x]. Bunyi konsonan dorso-velar [x] tidak dapat dibentuk sebab pangkal lidah tidak mampu untuk ditekankan pada langit-langit lunak, sehingga ruangan jalannya udara antara pangkal lidah dengan langit-langit lunak tidak terbentuk dan menyebabkan tidak ada udara yang keluar dan bergeser. Hal ini kemungkinan disebabkan oleh lidah Bagus Chandra yang terlalu lebar sehingga lidah tidak leluasa untuk menekan langit-langit lunak.

\section{Bunyi Konsonan Lamino-alveolar [z]}

Bunyi konsonan lamino-alveolar [z]. Dalam proses pembentukan bunyi konsonan tersebut, artikulator aktif yang berperan adalah daun lidah dan ujung lidah sedangkan artikulator pasifnya adalah gusi atas bagian belakang. Cara pembentukan bunyi konsonan [z] ini adalah dengan menekankan daun lidah dan ujung lidah pada gusi atas belakang, sehingga akan membentuk ruang untuk jalannya udara antara daun lidah dan gusi agar ada udara yang keluar dan bergeser membentuk bunyi konsonan lamino-alveolar [z]. Namun hal tersebut tidak mampu untuk dilakukan oleh Bagus Chandra, sebab keadaan lidahnya yang cukup panjang menghalanginya untuk menekankan daun lidah dan ujung lidah ke gusi atas bagian belakan. Dalam kondisi ini, bunyi konsonan lamino-alveolar [z] diganti dengan bunyi konsonan [j] yang dianggap lebih mudah untuk diucapkan.

Dari hasil analisis di atas, dapat dibuktikan bahwa faktor kesalahan pengucapan bunyi bahasa yang dialami oleh Bagus Chandra yang menyebabkan ia tidak mampu mengucapkan beberapa bunyi konsonan yang mencakup bunyi konsonan $[\mathrm{r}],[\mathrm{f}],[\mathrm{v}],[\mathrm{w}],[\mathrm{x}]$, dan $[\mathrm{z}]$ berdasarkan ciri fisiknya disebabkan oleh perkembangan tumbuh kembang lidah yang 
abnormal. Oleh sebab itu, dalam kondisi ini, perawatan yang dinilai tepat untuk dilakukan adalah dengan terapi wicara untuk melatih kelancaran dari gerak alat ucap yang lemah yaitu lidah, yang berperan sebagai artikulator aktif untuk membentuk bunyi konsonan yang tidak mampu Bagus Chandra ucapkan, yaitu bunyi konsonan yang mencakup bunyi konsonan apiko-alveolar [r], labio-dental [f], labio-dental [v], bilabial [w], dorso-velar [x], dan laminoalveolar

\section{SIMPULAN}

Pengucapan bunyi vokal dan sebagian besar bunyi konsonan Bagus Chandra adalah sempurna. Hal ini dibuktikan dengan analisis kemampuan seluruh bunyi vokal yang didasarkan pada distribusi dan letak silabe terbuka dan tertutup yang mencakup bunyi vokal [a], [i], [u], [ə][e], dan [o] yang dapat Bagus Chandra ucapkan dengan tepat. Sebagian besar bunyi konsonan dapat ia ucapkan dengan tepat, yang mencakup bunyi konsonan [b], [c], [d], [g], [h], [j], [k], [1], [m], [n], [p], [q], [s], [t], dan [y]. Namun, dalam hal ini hanya sebagian kecil dari bunyi konsonan yang mencakup bunyi konsonan [r], [f], [v], [w], [x], dan [z] yang tidak mampu diucapkan dengan sempurna. Ketidakmampuan pengucapan bunyi konsonan tersebut dapat dikatakan terbentuk akibat gerak lidah yang tidak leluasa dalam membentuk bunyi apiko-alveolar [r], lamino-dental [f] dan [v], bilabial [w], dorso-velar [x], dan laminoalveolar $[\mathrm{z}]$, yang disebut dengan penyimpangan bunyi bahasa. Ketidakmampuan pengucapan beberapa bunyi konsonan tersebut secara fisik diakibatkan oleh ukuran lidah Bagus Chandra terlalu panjang dan lebar dari ukuran normal dan sering dijulurkan meskipun dalam keadaan lidah sedang istirahat. Sebagian besar penyimpangan bunyi bahasa adalah penyimpangan yang bersifat penyisipan (addition), penghilangan (omission), dan penggantian (substitution). Penyimpangan bunyi bahasa dalam hal ini bersifat berulang-ulang.

\section{DAFTAR PUSTAKA}

Baihaqi M, L. 2011. "Kompetensi Fonologis Anak Penyandang Down Syndrome di SLB C Negeri 1 Yogyakarta”. Repository Kemendikbud. Widyariset Volume 14 No 1. http://repositori.perpustakaan.kemdikbud.go.id/428/1/401-786-1-SM.pdf.

Chaer, A. 2003. Fonologi. Jakarta: Rineka Cipta.

Cohen I, W; Nadel L., \& Madnick E, M. 2002. Visions For $21^{\text {st }}$ Century Down Syndrome. New York: A John Wiley \& Sons INC Publication.

Indah N, R. 2012. Gangguan Berbahasa. Malang: UIN-Maliki Press.

Khotimah, Ch. 2016. "Kajian Linguistik Klinis terhadap Gangguan Berbahasa Maulidiyah: Studi Kasus Anak Tunagrahita di SDLB Muhammadiyah Jombang”, Tesis. Jember: FIB Universitas Jember.

Mardiati, N. 2018. "Kemampuan Pelafalan Bunyi-bunyi Bahasa dalam Kosakata Dasar Bahasa Indonesia oleh Lutsiana Anak Tunagrahita Ringan SDLB Negeri Patrang Jember”. Skripsi. Jember: FIB Universitas Jember.

Muslich, M. 20014. Fonologi Bahasa Indonesia Tinjauan Deskriptif Sistem Bunyi Bahasa Indonesia. Jakarta: PT Bumi Aksara. 
Pruthi, G. 2007. "Language Development in Children with Mental Retardation”. University Press. www.goertzel.org.

Pujaningsih. 2010. "Perkembangan Bahasa dan Gangguan Berbahasa pada Anak Berkebutuhan Khusus". Jurnal Pendidikan Khusus. Volume 6 No 1. www.download.portalgaruda.org.

Roberts, E. J; Price, J;. Malkin, Ch. 2007. "Language and Communication Development in Down Syndrome". Mental Retardation and Developmental Disabilities Research Reviews. https://www.ncbi.nlm.nih.go.

Sardjono. 2005. Terapi Wicara. Yogyakarta: Pustaka Belajar.

Sudiono, J. 2014. Gangguan Tumbuh Kembang Dentokraniofasial. Jakarta: Penerbit Buku Kedokteran EGC.

Sugiyono. 2008. Metode Penelitian Kuantitatif, Kualitatif dan R\&D. Bandung: Alfabet. 